\title{
Correction to: Altererythrobacter flava sp. nov., a new member of the family Erythrobacteraceae, isolated from a surface seawater sample
}

\author{
Xiao-Mei Zhang • Dao-Feng Zhang (1) Y Yuan-Lan Zhang
}

Published online: 7 December 2021

(C) Springer Nature Switzerland AG 2021

\section{Correction to:}

Antonie van Leeuwenhoek (2021) 114:497-506

https://doi.org/10.1007/s10482-021-01531-9

In the original publication of the article, the name that we proposed for the novel species is malformed as it contravenes Rule 12c (1) of the ICNP. The correct name should be "Altererythrobacter flavus" across the paper, and this name becomes a heterotypic synonym of Altererythrobacter flavus Ma et al. 2018 (DOI https://doi.org/10.1099/ijsem.0.002822). Altererythrobacter flavus Ma et al. 2018 is a homotypic synonym of Tsuneonella flava (Ma et al. 2018) Xu et al. 2020 (DOI https://doi.org/10.1099/ijsem.0.004293).

The original article can be found online at https:// doi.org/10.1007/s10482-021-01531-9.

X.-M. Zhang

College of Basic Medicine, Yunnan University of Chinese

Medicine, Kunming 650500, People's Republic of China

\section{D.-F. Zhang ( $\square)$}

Institute of Marine Biotechnology and Bio-Resource

Utilization, College of Oceanography, Hohai University,

Nanjing 210098, People's Republic of China

e-mail: zdf1987@163.com

Y.-L. Zhang $(\bowtie)$

Co-Innovation Center for Sustainable Forestry in

Southern China, Nanjing Forestry University,

Nanjing 210037, People's Republic of China

e-mail: ylz@njfu.edu.cn
In the section of species description, the sentence "Altererythrobacter flava (fla'va L. fem. adj. flava, yellow, referring to the colony colour of the type strain)" should be replaced as "Altererythrobacter flavus (fla'vus. L. masc. adj. flavus, yellow, referring to the colony colour of the type strain)".

Publisher's Note Springer Nature remains neutral with regard to jurisdictional claims in published maps and institutional affiliations. 